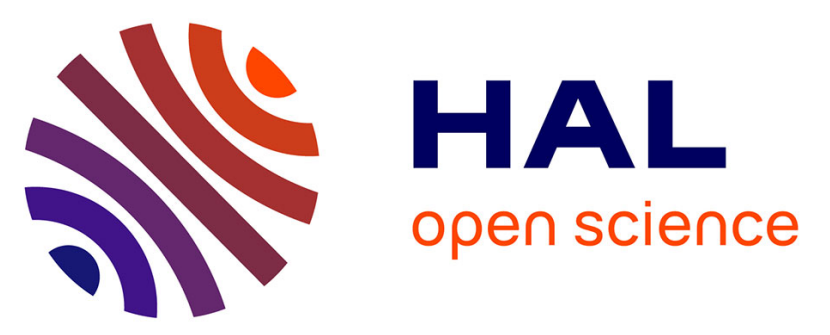

\title{
The cluster compound In4Ti1.5Mo0.5Mo14O26 containing Mo14 clusters and the new mono- and bi-capped trioctahedral Mo15 and Mo16 clusters: Synthesis, crystal structure, and electrical and magnetic properties.
}

Philippe Gall, Thierry Guizouarn, Patrick Gougeon

\section{To cite this version:}

Philippe Gall, Thierry Guizouarn, Patrick Gougeon. The cluster compound In4Ti1.5Mo0.5Mo14O26 containing Mo14 clusters and the new mono- and bi-capped trioctahedral Mo15 and Mo16 clusters: Synthesis, crystal structure, and electrical and magnetic properties.. Journal of Solid State Chemistry, 2015, 227, pp.98-103. 10.1016/j.jssc.2015.03.030 . hal-01153431

HAL Id: hal-01153431

https://hal-univ-rennes1.archives-ouvertes.fr/hal-01153431

Submitted on 4 Nov 2015

HAL is a multi-disciplinary open access archive for the deposit and dissemination of scientific research documents, whether they are published or not. The documents may come from teaching and research institutions in France or abroad, or from public or private research centers.
L'archive ouverte pluridisciplinaire HAL, est destinée au dépôt et à la diffusion de documents scientifiques de niveau recherche, publiés ou non, émanant des établissements d'enseignement et de recherche français ou étrangers, des laboratoires publics ou privés. 
The cluster compound $\mathrm{In}_{4} \mathrm{Ti}_{1.5} \mathrm{Mo}_{0.5} \mathrm{Mo}_{14} \mathrm{O}_{26}$ containing $\mathrm{Mo}_{14}$ clusters and the new mono- and bi-capped trioctahedral $\mathrm{Mo}_{15}$ and $\mathrm{Mo}_{16}$ clusters: synthesis, crystal structure, and electrical and magnetic properties.

\section{Philippe Gall, Thierry Guizouarn and Patrick Gougeon*}

Laboratoire de Chimie du Solide et Inorganique Moléculaire, UMR CNRS 6226 - INSA,

Université de Rennes 1, Avenue du Général Leclerc, 35042 Rennes-Cedex, France.

Corresponding Author

Fax: Int. Code + 2232367 99; E-mail: Patrick.Gougeon@univ-rennes1.fr

Abstract

Single crystals of the new quaternary compound $\operatorname{In}_{4} \mathrm{Ti}_{1.5} \mathrm{Mo}_{0.5} \mathrm{Mo}_{14} \mathrm{O}_{26}$ were obtained by solid state reaction. The crystal structure was determined by single-crystal X-ray diffraction. $\mathrm{In}_{4} \mathrm{Ti}_{1.5} \mathrm{Mo}_{0.5} \mathrm{Moo}_{14} \mathrm{O}_{26}$ crystallizes in the orthorhombic space group Pbca with unit-cell parameters $\mathrm{a}=9.4432(14) \AA, \mathrm{b}=11.4828(12) \AA, \mathrm{c}=20.299$ (4) $\AA$ and $\mathrm{Z}=4$. Full-matrix least-squares refinement on $\mathrm{F}^{2}$ using 3807 independent reflections for 219 refinable parameters resulted in $\mathrm{R}_{1}=0.0259$ and $w \mathrm{R}_{2}=0.0591$. The crystal structure contains in addition to $\mathrm{Mo}_{14}$ clusters the first examples of mono- and bi-capped trioctahedral $\mathrm{Mo}_{14}$ i.e. $\mathrm{Mo}_{15}$ and $\mathrm{Mo}_{16}$ clusters. The oxygen framework derives from a stacking along the a direction of close-packed layers with sequence (...ABAC...). The Mo-Mo distances range between 2.6938(5) and 2.8420(6) $\AA$ and the Mo-O distances between 1.879(5) and 2.250(3) $\AA$, as usually observed in molybdenum oxide clusters. The indium atoms form $\mathrm{In}_{4}{ }^{6+}$ bent chains with In-In distances of 2.6682(5) and 2.6622(8) $\AA$ and the Ti atoms are in highly distorted octahedral sites of oxygen atoms with Ti-O distances ranging between 1.865(4) and 2.161(4) $\AA$. Magnetic susceptibility measurements confirm the presence of $\mathrm{Ti}^{4+}$ cations and the absence 
of localized moments on the Mo network. Electrical resistivity measurements on a single crystal of $\operatorname{In}_{4} \mathrm{Ti}_{1.5} \mathrm{Mo}_{0.5} \mathrm{Mo}_{14} \mathrm{O}_{26}$ show a semimetallic behavior.

Keywords

Reduced molybdenum oxide, molybdenum clusters, disordered crystal structure, magnetic susceptibility, resistivity measurement.

\section{INTRODUCTION}

In solid state chemistry, the octahedral $\mathrm{M}_{6}$ cluster constitutes the main structural feature of numerous ternary or quaternary chalcogenide, chalcohalide or halide compounds containing transition metals such as $\mathrm{Nb}, \mathrm{Mo}, \mathrm{Ta}, \mathrm{W}$ or Re in low oxidation states. Larger clusters which are principally observed with the molybdenum, result either from the uniaxial face- or edgesharing of $\mathrm{Mo}_{6}$ octahedra. The former process is observed when the $\mathrm{Mo}_{6}$ clusters are facebridged by the ligands such as $\mathrm{S}, \mathrm{Se}$ and $\mathrm{Te}$ and is exemplified by the series of compounds $\mathrm{M}_{\mathrm{n}-2} \mathrm{Mo}_{3 \mathrm{n}} \mathrm{X}_{3 \mathrm{n}+2}\left(\mathrm{M}=\mathrm{Rb}, \mathrm{Cs} ; \mathrm{X}=\mathrm{S}, \mathrm{Se}\right.$ or Te; $\mathrm{n}=3,4,5,6,7,8$ and 10) containing $\mathrm{Mo}_{9}$, $\mathrm{Mo}_{12}, \mathrm{Mo}_{15}, \mathrm{Mo}_{18}, \mathrm{Mo}_{21}, \mathrm{Mo}_{24}, \mathrm{Mo}_{30}$ and $\mathrm{Mo}_{36}$ clusters [1]. The final stage of this facesharing condensation is the infinite $\left|\mathrm{Mo}_{6 / 2}\right|_{\infty}^{1}$ chain found in the quasi-one-dimensional compounds $\mathrm{M}_{2} \mathrm{Mo}_{6} \mathrm{X}_{6}\left(\mathrm{M}=\mathrm{Na}, \mathrm{K}, \mathrm{Rb}, \mathrm{Cs} ; \mathrm{X}=\mathrm{S}\right.$, Se or Te) [2] and $\mathrm{AgMo}_{6} \mathrm{Te}_{6}$ [3]. The edgesharing condensation of $\mathrm{Mo}_{6}$ octahedra is observed in the reduced molybdenum oxides where the $\mathrm{Mo}_{6}$ clusters are edge-bridged by the oxygens. This process leads to columnar bi [4], tri [5], tetra [6] and penta-octahedral [7] oligomers that are observed for example in the series $\mathrm{M}_{\mathrm{n}-\mathrm{x}} \mathrm{Mo}_{4 \mathrm{n}+2} \mathrm{O}_{6 \mathrm{n}+4}(\mathrm{n}=2,3,4$ and 5). The ultimate step of the edge-sharing-condensation process corresponds to the infinite $\left|\mathrm{Mo}_{2} \mathrm{Mo}_{4 / 2}\right|_{\infty}^{1}$ chain of trans-edge-sharing $\mathrm{Mo}_{6}$ octahedra that was first observed in $\mathrm{NaMo}_{4} \mathrm{O}_{6}[8]$ and subsequently in the isostructural $\mathrm{M}_{\mathrm{x}} \mathrm{Mo}_{4} \mathrm{O}_{6}(\mathrm{M}=$ $\mathrm{K}$ [9], $\mathrm{Ba}[10]$, In [11], $\mathrm{Sn}$ [12] or $\mathrm{Pb}$ ) compounds and in the four other structure-types $\mathrm{Sc}_{0.75} \mathrm{Zn}_{1.25} \mathrm{Mo}_{4} \mathrm{O}_{7}$ [13], $\mathrm{Mn}_{1.5} \mathrm{Mo}_{8} \mathrm{O}_{11}$ [14], $\mathrm{MMo}_{8} \mathrm{O}_{10}(\mathrm{M}=\mathrm{Li}, \mathrm{Zn})$ [15] and $\mathrm{R}_{4} \mathrm{Mo}_{4} \mathrm{O}_{11}$ [16]. 
In reduced molybdenum oxides, related clusters to $\mathrm{Mo}_{6}$ and $\mathrm{Mo}_{10}$ were also obtained by capping some faces. For example, the existence of mono- and bi-capped $\mathrm{Mo}_{6}$ clusters, i.e. $\mathrm{Mo}_{7}$ and $\mathrm{Mo}_{8}$, was first mentioned by Leligny et al. in the compound $\mathrm{LaMo}_{7.7} \mathrm{O}_{14}$ [17] in which both clusters coexist randomly. Subsequently, the $\mathrm{Mo}_{7}$ and $\mathrm{Mo}_{8}$ clusters were found in well-ordered structures. The monocapped octahedral $\mathrm{Mo}_{7}$ unit has been observed up to now either forming infinite chains with bioctahedral $\mathrm{Mo}_{10}$ unit or quasi-isolated in the series of compounds $\mathrm{M}_{4} \mathrm{M}_{3}{ }_{3} \mathrm{Mo}_{26} \mathrm{O}_{48}\left(\mathrm{M}=\mathrm{Sr}, \mathrm{Eu}, \mathrm{Mo}{ }^{\prime}=\mathrm{Al}, \mathrm{Ga}, \mathrm{Fe}\right)$ [18]. The bi-capped octahedral Mo8 cluster was encountered in the two isomeric cis and trans forms in the series of polymorphic compounds $\mathrm{RMo}_{8} \mathrm{O}_{14}(\mathrm{R}=\mathrm{La}, \mathrm{Ce}, \mathrm{Pr}, \mathrm{Nd}, \mathrm{Sm})$ [19]. In addition, the $\mathrm{Mo}_{9}$ and $\mathrm{Mo}_{10}$ clusters formed by capping three or four faces of the octahedral $\mathrm{Mo}_{6}$ were observed in the modulated compound $\mathrm{EuMo}_{7.96} \mathrm{O}_{14}$ [20]. More recently, the $\mathrm{Mo}_{11}$ and $\mathrm{Mo}_{12}$ clusters resulting from the capping of one and two faces of the bioctahedral $\mathrm{Mo}_{10}$ cluster were observed in the quaternary reduced molybdenum oxides $\mathrm{M}_{2} \mathrm{Ti}_{1.4} \mathrm{Mo}_{0.6} \mathrm{Mo}_{10} \mathrm{O}_{20}(\mathrm{M}=\mathrm{Sr}, \mathrm{Eu})$ [21]. In the latter compounds, the Mo network is dominated by bioctahedral $\mathrm{Mo}_{10}$ clusters, which coexist statiscally with $\mathrm{Mo}_{11}$ and $\mathrm{Mo}_{12}$ clusters. In this work, we show how the facecapping principle can be extended to trioctahedral $\mathrm{Mo}_{14}$ units formed by fusing three $\mathrm{Mo}_{6}$ clusters with the synthesis, crystal structure, and physical properties of the new compound $\mathrm{In}_{4} \mathrm{Ti}_{1.5} \mathrm{Mo}_{0.5} \mathrm{Mo}_{14} \mathrm{O}_{26}$. This latter compound contains in addition to $\mathrm{Mo}_{14}$ clusters the first examples of mono- and bi-capped trioctahedral $\mathrm{Mo}_{14}$ clusters i.e. $\mathrm{Mo}_{15}$ and $\mathrm{Mo}_{16}$ clusters. 


\section{EXPERIMENTAL}

Synthesis

$\mathrm{In}_{4} \mathrm{Ti}_{1.5} \mathrm{Mo}_{0.5} \mathrm{Mo}_{14} \mathrm{O}_{26}$ was obtained as single crystals by heating a mixture of $\operatorname{In}_{2} \mathrm{O}_{3}, \mathrm{TiO}_{2}$, $\mathrm{MoO}_{3}$ and Mo with the overall composition "In2TiMo4O8" at $1400^{\circ} \mathrm{C}$ for $96 \mathrm{H}$ in a sealed molybdenum crucible. The latter was previously cleaned by heating at about $1500{ }^{\circ} \mathrm{C}$ for 15 $\mathrm{mn}$ under a dynamic vacuum of about $10^{-5}$ Torr. The mixture of the starting materials was pressed into a pellet and loaded into a molybdenum crucible which was sealed under a low argon pressure using an arc welding system. The composition of the thus obtained crystals was proved to from single-crystal X-ray diffraction data (see below). Attempts made to prepare a single-phase powder of $\operatorname{In}_{4} \mathrm{Ti}_{1.5} \mathrm{Mo}_{0.5} \mathrm{Mo}_{14} \mathrm{O}_{26}$ were unsuccessful (only approximate yields of 15 to $25 \%$ were obtained).

Single Crystal X-ray Study

A black crystal of approximate dimensions $0.196 \times 0.037 \mathrm{x} 0.025 \mathrm{~mm}^{3}$ was employed in the intensity data collection conducted with a Nonius KappaCCD diffractometer. The COLLECT program package [22] was used to establish the angular scan conditions ( $\phi$ and $\omega$ scans) used in the data collection. A total of 317 frames were collected with a frame width of $1.10^{\circ}$ and an exposure time of $66 \mathrm{~s}$. Reflection indexing, Lorentz-polarization correction, peak integration, and background determination were performed by using the EvalCCD program [23]. An absorption correction ( $\min / \max$ transmission=0.5744/0.6063) was applied using the description of the crystal faces [24]. Of 54877 reflections collected in the 3.56-36.2 $\theta$ range, 5281 were independent $(\operatorname{Rint}=0.0502)$. Analysis of the data revealed that the systematic absences $(0 \mathrm{kl}) \mathrm{k}=2 \mathrm{n}+1$, (h0l) $\mathrm{l}=2 \mathrm{n}+1$, and (hk0) $\mathrm{h}=2 \mathrm{n}+1$ were consistent with the orthorhombic space group Pbca. The initial positions for 7 molybdenum atoms forming a $\mathrm{Mo}_{14}$ cluster and some of the oxygen atoms as well as for the indium atom were determined with the direct methods program SIR-97 [25] in the Pbca space group. A subsequent difference Fourier synthesis revealed the remaining oxygen atoms and two peaks at $0.42 \AA$ from each other. As this situation was similar to that encountered in the $\mathrm{M}_{2} \mathrm{Ti}_{1.4} \mathrm{Mo}_{0.6} \mathrm{Mo}_{10} \mathrm{O}_{20}$ $(\mathrm{M}=\mathrm{Sr}, \mathrm{Eu})$ compounds, the peak the closest to the $\mathrm{Mo}_{14}$ cluster was assigned to a Mo atom (Mo8) and the peak farthest to a Ti atom. Subsequent refinements of this model included the 
atomic position and anisotropic displacement parameters for all atoms as well as the site occupancy factors for the Mo8 and Ti atoms. The later ones which were first refined freely converged to $0.25(2)$ and $0.74(3)$, respectively. Consequently, in the final refinement the sum the site occupancy factors of the Mo8 and Ti atoms was fixed to unity. A calculation of the two Mo8 and Ti probability density functions shows that they do not overlap and that for both atoms the position of the density maximum coincides with the refined position. The final fullmatrix least squares refinement on $\mathrm{F}^{2}$ which was based on a model including the positional and anisotropic displacement parameters for all atoms and site occupancy factors for Ti and Mo8 led to the values of $R=0.0259$ and $w R=0.0591$ for 3807 reflections with $I>2 \sigma(I)$ and to the stoichiometry $\operatorname{In}_{4} \mathrm{Ti}_{1.5} \mathrm{Mo}_{0.5} \mathrm{Mo}_{14} \mathrm{O}_{26}$. All structure refinements and Fourier syntheses were carried out using SHELXL-97 [26]. Reconstructed reciprocal space sections did not show any superlattice reflexions or diffuse lines that preclude a possible ordering of the different clusters. Crystallographic data and X-ray structural analysis for the $\mathrm{In}_{4} \mathrm{Ti}_{1.5} \mathrm{Mo}_{0.5} \mathrm{Mo}_{14} \mathrm{O}_{26}$ compound are summarized in Table 1. The final atomic coordinates, and the equivalent isotropic displacement parameters are gathered in Table S1, and selected interatomic distances are listed in Table S2 in the Supporting information. Further details of the crystal structure investigation can be obtained from the Fachinformationszentrum Karlsruhe, 76344 Eggenstein-Leopoldshafen, Germany, (fax: (49) 7247-808-666; e-mail: crysdata@ fiz.karlsruhe.de) on quoting the depository number CSD- 428999.

\section{Electrical Resistivity Measurements}

The study of the temperature dependence of the electrical resistivity was carried out on a single crystal of $\operatorname{In}_{4} \mathrm{Ti}_{1.5} \mathrm{Mo}_{0.5} \mathrm{Mo}_{14} \mathrm{O}_{26}$ using a conventional ac four-probe method with a current amplitude of $0.1 \mathrm{~mA}$. Contacts were ultrasonically made with molten indium on the single crystal. The ohmic behavior and the invariance of the phase were checked during the different measurements at low and room temperature.

Magnetic susceptibility measurements.

Susceptibility data were collected on a batch of single crystals (ca. $40 \mathrm{mg}$ ) using a Quantum Design SQUID magnetometer between $2 \mathrm{~K}$ and $400 \mathrm{~K}$ and at an applied field of $0.1 \mathrm{~T}$. 


\section{RESULT AND DISCUSSION}

Figure 1 shows the projections of the crystal structures of $\operatorname{In}_{4} \mathrm{Ti}_{1.5} \mathrm{Mo}_{0.5} \mathrm{Mo}_{14} \mathrm{O}_{26}$ and $\mathrm{M}_{2} \mathrm{Ti}_{1.4} \mathrm{Mo}_{0.6} \mathrm{Mo}_{10} \mathrm{O}_{20}(\mathrm{M}=\mathrm{Sr}$, Eu $)$ on the (b, c) plane. From these figures, the structural relationship between the two structure types, which are both described in the space group Pbca, is evident.

The main structural feature of $\operatorname{In}_{4} \mathrm{Ti}_{1.5} \mathrm{Mo}_{0.5} \mathrm{Mo}_{14} \mathrm{O}_{26}$ is the presence of trioctahedral edgesharing $\mathrm{Mo}_{14}$, and mono- and bi-capped $\mathrm{Mo}_{15}$ and $\mathrm{Mo}_{16}$ clusters which coexist statistically due to the partial occupancy of the capping site Mo8 shown in light blue in Figure 2a. The Fig. 3 shows a perspective view of the crystal structure of $\operatorname{In}_{4} \operatorname{Ti}_{1.5} \mathrm{Mo}_{0.5} \mathrm{Mo}_{14} \mathrm{O}_{26}$ along the $\mathrm{b}$ axis. As in the $\mathrm{M}_{2} \mathrm{Ti}_{1.4} \mathrm{Mo}_{0.6} \mathrm{Mo}_{10} \mathrm{O}_{20}$ compounds, the oxygen framework derives from a stacking along the a direction of close-packed layers with sequence (...ABAC...). Projections of the four layers onto the (100) plane are given in Fig. 4. While the $\mathrm{B}(\mathrm{y} \sim 0.25)$ and $\mathrm{C}(\mathrm{y} \sim$ 0.75 ) layers are entirely occupied by oxygen atoms (Figures $4 \mathrm{~b}$ and $4 \mathrm{~d}$, respectively) and have the composition [O32], in the A layers (y 0.0 and 0.5) one fourth of the oxygen atoms are substituted by the In ions and one eighth are missing in an ordered way (Figures $4 \mathrm{a}$ and $4 \mathrm{c}$, respectively). Consequently, the latter layers can be formulated [O20In8 $\square 4$ ] where $\square$ stands for the oxygen vacancies. Within the $\mathrm{O}$ network, $7 / 13$ of the octahedral interstices are occupied by the Mo1 to Mo7 atoms which form trioctahedral $\mathrm{Mo}_{14}$ clusters and one thirteenth statistically by the capping Mo8 and Ti atoms. The trioctahedral $\mathrm{Mo}_{14}$ cluster which results from the metal-edge condensation of three octahedral $\mathrm{Mo}_{6}$-type clusters is similar to those previously observed in the compounds $\mathrm{T}_{1.6} \mathrm{Sn}_{1.2} \mathrm{Mo}_{14} \mathrm{O}_{22}$ [5a and b], $\mathrm{K}_{3} \mathrm{Mo}_{14} \mathrm{O}_{22}$, $\mathrm{K}_{1.66} \mathrm{~Pb}_{1.34} \mathrm{Mo}_{14} \mathrm{O}_{22}$, and $\mathrm{K}_{1.29} \mathrm{Sn}_{1.71} \mathrm{Mo}_{14} \mathrm{O}_{22}$ [5c]. It is also interesting to note that the vacancies in the A layers correspond to the center of the octahedra forming the $\mathrm{Mo}_{14}$ clusters. In the latter, the Mo-Mo distances range between 2.6938(5) and 2.8420(6) $\AA$ and the Mo-O distances between $1.879(5)$ and $2.250(3) \AA$, as usually observed in molybdenum oxide 
clusters. The shortest distances between the $\mathrm{Mo}_{14}$ cluster and the capping Mo8 atom agree well with the existence of metallic bonds: 2.798(10) $\AA$ for Mo8-Mo1, 2.864(10) $̊$ for Mo8Mo2 and 2.802(10) $\AA$ for Mo8-Mo3 (see Fig. 2a), leading thus to the formation of monocapped and bicapped bioctahedral $\mathrm{Mo}_{15}$ and $\mathrm{Mo}_{16}$ clusters (Fig. $2 \mathrm{~b}$ and 2c). The latter clusters which are new to solid-state chemistry coexist thus randomly with the $\mathrm{Mo}_{14}$ clusters in $\operatorname{In}_{4} \mathrm{Ti}_{1.5} \mathrm{Mo}_{0.5} \mathrm{Mo}_{14} \mathrm{O}_{26}$. Moreover, it should be noted that the distances between the $\mathrm{Mo}_{14}$ clusters and the $\mathrm{Ti}$ atoms which are greater than $3.15 \AA$ preclude the presence of heteronuclear clusters such as $\mathrm{Mo}_{14} \mathrm{Ti}$ or $\mathrm{Mo}_{14} \mathrm{Ti}_{2}$ as previously mentioned for the $\mathrm{M}_{2} \mathrm{Ti}_{1.4} \mathrm{Mo}_{0.6} \mathrm{Mo}_{10} \mathrm{O}_{20}(\mathrm{M}=\mathrm{Sr}, \mathrm{Eu})$ compounds. The Ti atoms are surrounded by six oxygen atoms forming a highly distorted octahedron (Figure 6). The Ti-O distances range between 1.865(4) and 2.161(4) $\AA$ with a mean value of $2.01 \AA$ closed to the value of $2.00 \AA$ calculated from the sum of the ionic radii of $\mathrm{O}^{2-}$ and $\mathrm{Ti}^{4+}$ in octahedral coordination according to Shannon and Prewitt [27]. From the Ti-O bond lengths, the valence of the Ti atoms calculated by using the relationship of Brown and $\mathrm{Wu}\left[\left(\mathrm{s}=(\mathrm{dTi}-\mathrm{O} / 1.806)^{-5.2}\right)\right][28]$ is +3.7 , suggesting a number of oxidation of +4 . This confirms the tetravalence of the titanium that was already proved by XPS measurements in $\mathrm{Eu}_{2} \mathrm{Ti}_{1.4} \mathrm{Mo}_{0.6} \mathrm{Mo}_{10} \mathrm{O}_{20}$. Another interesting structural feature in $\mathrm{In}_{4} \mathrm{Ti}_{1.5} \mathrm{Mo}_{0.5} \mathrm{Mo}_{14} \mathrm{O}_{26}$ is the presence of indium forming an $\mathrm{In}_{4}{ }^{6+}$ bent chain shown in Fig. 5 . The two indium distances In1-In2 and In2-In2 are quite comparable, 2.6682(5) and 2.6622(8) $\AA$, respectively. These distances are also of the same order as those observed for the $\operatorname{In}_{5}{ }^{7+}$ chains found in $\operatorname{In}_{5} \mathrm{Mo}_{18} \mathrm{O}_{28}$ [29] and $\operatorname{In}_{11} \mathrm{Mo}_{40} \mathrm{O}_{62}$ [30] which are comprised between 2.616 and $2.665 \AA$ and for the $\operatorname{In}_{6}{ }^{8+}$ chains in $\operatorname{In}_{3} \mathrm{Mo}_{11} \mathrm{O}_{17}$ and $\operatorname{In}_{11} \mathrm{Mo}_{40} \mathrm{O}_{62}$ which range from 2.645 to $2.689 \AA$.

An astonishing fact is the very close stoichiometry of the $\mathrm{Ti}$ and Mo capping atoms found in the $\mathrm{M}_{2} \mathrm{Ti}_{1.4} \mathrm{Mo}_{0.6} \mathrm{Mo}_{10} \mathrm{O}_{20}(\mathrm{M}=\mathrm{Sr}, \mathrm{Eu})$ compounds and $\mathrm{In}_{4} \mathrm{Ti}_{1.5} \mathrm{Mo}_{0.5} \mathrm{Mo}_{14} \mathrm{O}_{26}$ which is not 
understood to date. An intriguing question is also why any variation in the ratio $\mathrm{Mo} / \mathrm{Ti}$ led to multiphasic products in the case of the $\mathrm{M}_{2} \mathrm{Ti}_{1.4} \mathrm{Mo}_{0.6} \mathrm{Mo}_{10} \mathrm{O}_{20}(\mathrm{M}=\mathrm{Sr}, \mathrm{Eu})$ compounds?

Magnetic Properties. The temperature dependence of the molar magnetic susceptibility of $\mathrm{In}_{4} \mathrm{Ti}_{1.5} \mathrm{Mo}_{0.5} \mathrm{Mo}_{14} \mathrm{O}_{26}$ is shown in Figure 6. The susceptibility is nearly temperatureindependent in the range $100-300 \mathrm{~K}$ with $\chi_{\mathrm{RT}}=3.410-3 \mathrm{emu} / \mathrm{mol}$. This indicates clearly the absence of localized moments on the different Mo clusters as well as on the Ti atoms reflecting their tretravalence as previously observed in the $\mathrm{M}_{2} \mathrm{Ti}_{1.4} \mathrm{Mo}_{0.6} \mathrm{Mo}_{10} \mathrm{O}_{20}(\mathrm{M}=\mathrm{Sr}, \mathrm{Eu})$ series. The low-temperature upturn results probably from small amounts of paramagnetic impurities often present in the starting reactants.

The electrical resistivity of a single-crystal of $\operatorname{In}_{4} \mathrm{Ti}_{1.5} \mathrm{Mo}_{0.5} \mathrm{Mo}_{14} \mathrm{O}_{26}$ as a function of the temperature is shown in Figure 7. $\operatorname{In}_{4} \mathrm{Ti}_{1.5} \mathrm{Mo}_{0.5} \mathrm{Mo}_{14} \mathrm{O}_{26}$ presents a poorly metallic behavior with a transition to a semiconducting state below $50 \mathrm{~K}$ and a room temperature resistivity value of $510^{-3} \Omega \mathrm{cm}$. The poor metallic character of this compound probably results from the positional disorder of the clusters as previously observed for the $\mathrm{M}_{2} \mathrm{Ti}_{1.4} \mathrm{Mo}_{0.6} \mathrm{Mo}_{10} \mathrm{O}_{20}(\mathrm{M}=$ $\mathrm{Sr}, \mathrm{Eu})$ compounds.

\section{CONCLUSION}

In summary, the novel reduced molybdenum oxide $\operatorname{In}_{4} \mathrm{Ti}_{1.5} \mathrm{Mo}_{0.5} \mathrm{Mo}_{14} \mathrm{O}_{26}$ has been synthesized by solid-state reaction at $1400^{\circ} \mathrm{C}$ for $96 \mathrm{~h}$ in sealed molybdenum crucibles. Its crystal structure contains in addition to $\mathrm{Mo}_{14}$ clusters the first examples of mono- and bicapped trioctahedral $\mathrm{Mo}_{14}$ that is $\mathrm{Mo}_{15}$ and $\mathrm{Mo}_{16}$ clusters. Magnetic susceptibility measurements confirm the presence of $\mathrm{Ti}^{4+}$ cations. Electrical resistivity measurements on a single crystal of $\operatorname{In}_{4} \mathrm{Ti}_{1.5} \mathrm{Mo}_{0.5} \mathrm{Mo}_{14} \mathrm{O}_{26}$ show a semimetallic behavior. The existence of $\mathrm{Mo}_{18}$ and $\mathrm{Mo}_{22}$ clusters in $\mathrm{Ba}_{3} \mathrm{Mo}_{18} \mathrm{O}_{28}$ [6] and $\operatorname{In}_{6} \mathrm{Mo}_{22} \mathrm{O}_{34}$ [7], respectively, lets us to envisage that 
the mono and bicapped principle can be extended to the latter two clusters leading thus to $\mathrm{Mo}_{19}, \mathrm{Mo}_{20}, \mathrm{Mo}_{23}$ and $\mathrm{Mo}_{24}$ clusters in compounds in which the Mo-Ti-O networks would have the compositions $\left(\mathrm{Ti}_{1.5} \mathrm{Mo}_{0.5}\right) \mathrm{Mo}_{18} \mathrm{O}_{32}$ and $\left(\mathrm{Ti}_{1.5} \mathrm{Mo}_{0.5}\right) \mathrm{Mo}_{22} \mathrm{O}_{38}$, respectively.

\section{References}

[1] (a) P. Gougeon Ph.D. Thesis, University of Rennes, 1984.

(b) P. Gougeon, M. Potel, J. Padiou and M. Sergent, Mater. Res. Bull. 22, 1087, (1987). (c) P. Gougeon, M. Potel, J. Padiou and M. Sergent, Mater. Res. Bull. 23, 453 (1988). (d) P. Gougeon, M. Potel, and M. Sergent, Acta Crystallogr. 1989, C45, 182.

(e) Gougeon, P.; Potel, M.; Sergent, M. Acta Crystallogr. 1989, C45, 1413.

(f) Gougeon, P.; Potel, M.; Sergent, M. Acta Crystallogr. 1990, C46, 2284.

(g) Thomas, C.; Picard, S.; Gautier, R.; Gougeon, P.; Potel, M. J. Alloys Compd. 1997, 262- 263, 305.

(h) Picard, S.; Gougeon, P.; Potel, M. Acta Crystallogr. 1997, C53, 1519.

(i) Gautier, R.; Picard, S.; Gougeon, P.; Potel, M. Mater. Res. Bull. 1999, 1, 93.

(j) Picard, S.; Potel, M.; Gougeon, P. Angew. Chem., Int. Ed. 1999, 38, 2034.

(k) Picard, S.; Halet, J.-F.; Gougeon, P.; Potel, M. Inorg. Chem. 1999, 38, 4455.

(1) Picard, S.; Saillard, J.-Y.; Gougeon, P.; Noel, H.; Potel, M. J. Solid State Chem. 2000, 155, 417.

(m) Picard, S.; Gougeon, P.; Potel, M. Acta Crystallogr. 2001, C57, 335.

(n) Picard, S.; Gougeon, P.; Potel, M., Acta Crystallogr. 2001, C57, 663-664.

[2] M. Potel, R. Chevrel, M. Sergent, Acta Crystallogr., Sect. B: Struct. Sci. 1980, 36, 1319.

[3] (a) P. Gougeon, M. Potel, J. Padiou, M. Sergent, J. Solid State Chem. 1987, 68, 137 142.

(b) Gougeon, P.; Potel, M.; Padiou, J.; Sergent, M., Journal of Solid State Chemistry 1987, 68, 137-142. 
[4] (a) Hibble, S. J. ; Cheetham, A. K.; Bogle, A. R. L.; Wakerley, H. R.; Cox, D. E. J. Am. Chem. Soc. 1988, 110, 3295.

(b) Dronskowski, R; Simon, A. Angew. Chem. Int. Ed. Engl. 1989, 28, 758.

(c) Gougeon, P.; Potel, M.; Sergent, M. Acta Cryst. 1990, C46, 1188.

(d) Gougeon, P.; Gall, P.; Sergent, M. Acta Cryst. 1991, C47, 421.

(e) Dronskowski, R; Simon, A.; Mertin, W. Z. anorg. Allg. Chem. 1991, 602, 49.

(f) Gall, P.; Gougeon, P. Acta Cryst. 1994, C50, 7.

(g) Gall, P.; Gougeon, P. Acta Cryst. 1994, C50, 1183.

[5] (a) Dronskowski, R; Simon, A.; Mertin. W. Z. anorg. Allg. Chem. 1991, 602, 49.

(b) Dronskowski, R; Simon, A. Acta Chem. Scand. 1991, 45, 850.

(c) Schimek, G. L.; Chen, S. C.; Mc Carley, R. E. Inorg. Chem. 1995, 34, 6130.

[6] Schimek, G. L.; Nagaki, D. A.; Mc Carley, R. E. Inorg. Chem. 1994, 33, 1259.

[7] (a) Dronskowski, R.; Mattausch, H. J.; Simon, A. Zeit. Anorg. Allg. Chem. 1993, 619, 1397.

(b) Schimek, G. L.; Mc Carley, R. E. J. Solid State Chem. 1994, 113, 345.

[8] C. C. Torardi, R. E. McCarley, J. Am. Chem. Soc. 1979, 101, 3963.

[13] Mc Carley, R. E. Philos. Trans. R. Soc. London A. 1982, 308, 41.

[14] (a) Carlson, C. D.; Brough, L. F.; Edwards, P. A.; McCarley, R. E. J. Less Com. Met., $1989,156,325$.

(b) Gall, P.; Gougeon, P., Acta Cryst. 2006, E62, I155-I157.

[15] Lii, K. H.; Mc Carley, R. E.; Kim, S.; Jacobson, R. A. J. Solid State Chem. 1986, 64, 347.

[16] (a) Gougeon, P.; Gall, P.; McCarley, R. E., Acta Cryst. 1991, C47, 1585-1588.

(b) Gall, P.; Barrier, N.; Gautier, R.; Gougeon, P., Inorg. Chem. 2002, 41, 2879-2885.

(c) Gall, P.; Gougeon, P., J. Solid State Chem. 2008, 181, 1-6. 
[17] Leligny, H.; Ledésert, M.; Labbé, Ph.; Raveau, B.; Mc Carroll, W.H. J. Solid State Chem. 1990, 87, 35 - 43.

[18] (a) Tortelier, J.; Gougeon, P. Acta Crystallogr. 1996, C 52, 1862.

(b) Tortelier, J.; Gougeon, P.; Ramanujachary, K. V.; Greenblatt, M. Mat. Res. Bull. $1998,8,1151$.

[19] (a) Gougeon, P.; Mc Carley, R. E. Acta Cryst. 1991, C47, 241.

(b) Kerihuel, G.; Gougeon, P.; Acta Cryst. 1995, C51, 787.

(c) Kerihuel, G.; Gougeon, P.; Acta Cryst. 1995, C51, 1475.

(d) Kerihuel, G.; Tortelier, J.; Gougeon, P.; Acta Cryst. 1996, C52, 2389.

(e) Tortelier, J.; Gougeon, P.; Acta Cryst. 1997, C53, 668.

(f) Gautier, R.; Andersen, O. K.; Gougeon, P.; Halet, J. F.; Canadell, E.; Martin, J. D., Inorg. Chem. 2002, 41, 4689-4699.

[20] Leligny, H.; Grebille, D.; Roussel, P.; Labbe, P.; Hervieu, M.; Raveau, B.; Tortelier,

J.; Gougeon, P., Acta Cryst. 1999, B55, 467-483.

[21] Tortelier, J.; Gougeon, P.; Gautier, R.; Berjoan, R., Inorg. Chem. 2001, 40, 2292-2297.

[22] Nonius BV (1999). COLLECT, data collection software, Nonius BV.

[23] Duisenberg, A. J. M. (1998). Reflections on Area Detectors, PhD thesis, Utrecht.

[24] de Meulenaer, J.; Tompa, H. Acta Crystallogr., Sect. A: Found. Crystallogr. 1965, 19, $1014-1018$.

[25] Altomare, A.; Burla, M.C.; Camalli, M.; Cascarano, G.L.; Giacovazzo, C.; Guagliardi, A.; Moliterni, A.G.G.; Polidori, G.,Spagna, R. J. Appl. Cryst. 1999, 32, 115.

[26] Sheldrick, G. M. (1997). SHELXL97, Program for the refinement of Crystal Structures. Univ. Of Göttingen, Germany.

[27] R.D. Shannon, C.T. Prewitt, Acta Crystallogr. B25 (1969) 925-946.

[28] I. D. Brown and K. K. Wu, Acta Crystallogr. B32 (1976) 1957. 
[29] Fais, E.; Borrmann, H.; Mattausch, Hj.; Simon, A., Z. Anorg. Allg. Chem. 1995, 621, 1178.

[30] Mattausch, Hj; Simon, A.; Peters, E. M., Inorg. Chem. 1986, 25, 3428-3433.

Table 1. X-ray Crystallographic and Experimental data for $\operatorname{In}_{4} \mathrm{Ti}_{1.5} \mathrm{Mo}_{0.5} \mathrm{Mo}_{14} \mathrm{O}_{26}$.

\begin{tabular}{|l|l|}
\hline Empirical formula & $\mathrm{In}_{4} \mathrm{Ti}_{1.5} \mathrm{Mo}_{0.5} \mathrm{Mo}_{14} \mathrm{O}_{26}$ \\
\hline Formula weight & 2339.22 \\
\hline Temperature & $293(2) \mathrm{K}$ \\
\hline Wavelength & $0.71069 \mathrm{~A}$ \\
\hline Crystal system, space group & orthorhombic, Pbca \\
\hline Unit cell dimensions & $\mathrm{a}=9.4432(14) \AA, \mathrm{b}=11.4828(12) \AA, \mathrm{c}=20.299(4) \AA$ \\
\hline Volume & $2201.1(6) \AA^{3}$ \\
\hline Z, Calculated density & $4,7.059 \mathrm{Mg} / \mathrm{m}^{3}$ \\
\hline Absorption coefficient & $12.662 \mathrm{~mm}{ }^{-1}$ \\
\hline F(000) & 4186 \\
\hline Crystal size & $0.050 \mathrm{x} 0.058 \times 0.093 \mathrm{~mm}$ \\
\hline Theta range for data collection & 3.55 to 31.99 deg. \\
\hline Limiting indices & $-14<=\mathrm{h}<=14,-17<=\mathrm{k}<=15,-30<=\mathrm{l}<=28$ \\
\hline Reflections collected / unique & $43390 / 3807[\mathrm{R}(\mathrm{int})=0.0465]$ \\
\hline Completeness to theta = 31.99 & $99.8 \%$ \\
\hline Refinement method & Full-matrix least-squares on $\mathrm{F}^{2}$ \\
\hline Data / restraints / parameters & $3807 / 0 / 219$ \\
\hline Goodness-of-fit on F $\mathrm{F}^{2}$ & 1.140 \\
\hline Final R indices [I $>2 \sigma(\mathrm{I})]$ & $\mathrm{R} 1=0.0259, \mathrm{wR} 2=0.0591$ \\
\hline R indices (all data) & $\mathrm{R} 1=0.0316, \mathrm{wR} 2=0.0620$ \\
\hline Extinction coefficient & $0.00044(2)$ \\
\hline Largest diff. peak and hole & 1.829 and $-2.241 \mathrm{e} . \AA^{-3}$ \\
\hline
\end{tabular}




\section{FIGURE CAPTIONS}

Figure 1. Projections of the crystal structures of (a) $\operatorname{In}_{4} \mathrm{Ti}_{1.5} \mathrm{Mo}_{0.5} \mathrm{Mo}_{14} \mathrm{O}_{26}$ and (b) $\mathrm{M}_{2} \mathrm{Ti}_{1.4} \mathrm{Mo}_{0.6} \mathrm{Mo}_{10} \mathrm{O}_{20}(\mathrm{M}=\mathrm{Sr}, \mathrm{Eu})$ compounds on the $(\mathrm{b}, \mathrm{c})$ plane.

Figure 2. The (a) $\mathrm{Mo}_{14}$, (b) $\mathrm{Mo}_{15}$, and (c) $\mathrm{Mo}_{16}$ clusters with their oxygen and titanium environnements.

Figure 3. Perspective view of the crystal structure of $\operatorname{In}_{4} \mathrm{Ti}_{1.5} \mathrm{Mo}_{0.5} \mathrm{Mo}_{14} \mathrm{O}_{26}$ along the $b$ axis.

Figure 4. Arrangement of the oxygen and indium atoms within the $A B A C$ layers.

Figure 5. The tetrameric cation $\operatorname{In}_{4}{ }^{6+}$ with its oxygen environment.

Figure 6. The temperature dependence of the molar magnetic susceptibility of $\mathrm{In}_{4} \mathrm{Ti}_{1.5} \mathrm{Mo}_{0.5} \mathrm{Mo}_{14} \mathrm{O}_{26}$

Figure 7. Temperature dependence of the electrical resistivity for $\operatorname{In}_{4} \mathrm{Ti}_{1.5} \mathrm{Mo}_{0.5} \mathrm{Mo}_{14} \mathrm{O}_{26}$.

TABLE CAPTIONS

Table 1. X-ray Crystallographic and Experimental data for $\operatorname{In}_{4} \mathrm{Ti}_{1.5} \mathrm{Mo}_{0.5} \mathrm{Mo}_{14} \mathrm{O}_{26}$. 


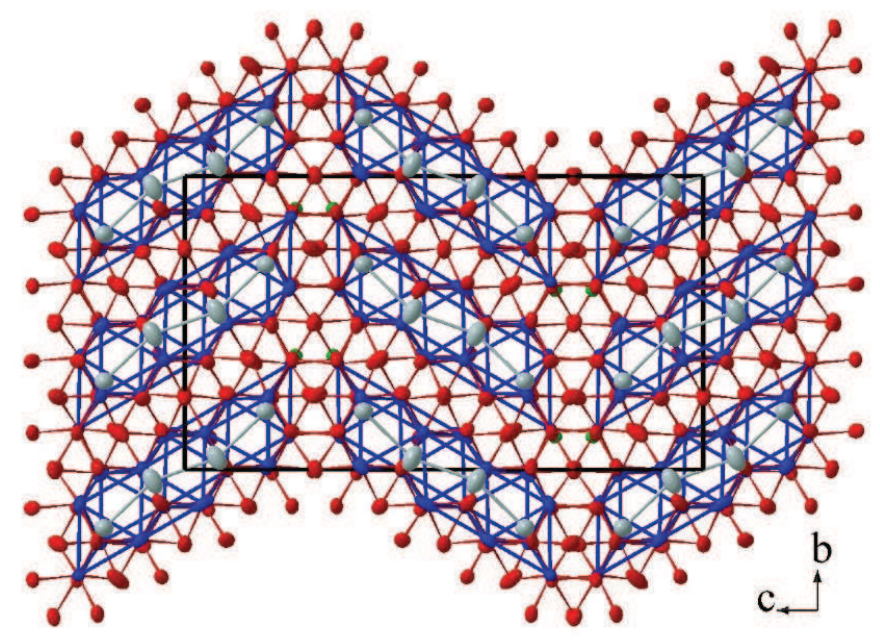

(a)

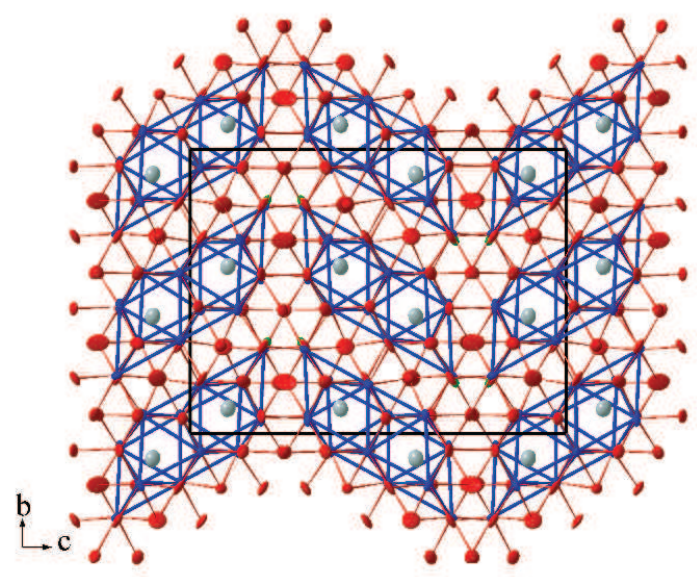

(b)

Figure 1. Projections of the crystal structures of (a) $\operatorname{In}_{4} \mathrm{Ti}_{1.5} \mathrm{Mo}_{0.5} \mathrm{Mo}_{14} \mathrm{O}_{26}$ and (b) $\mathrm{M}_{2} \mathrm{Ti}_{1.4} \mathrm{Mo}_{0.6} \mathrm{Mo}_{10} \mathrm{O}_{20}(\mathrm{M}=\mathrm{Sr}, \mathrm{Eu})$ compounds on the (b, c) plane. 


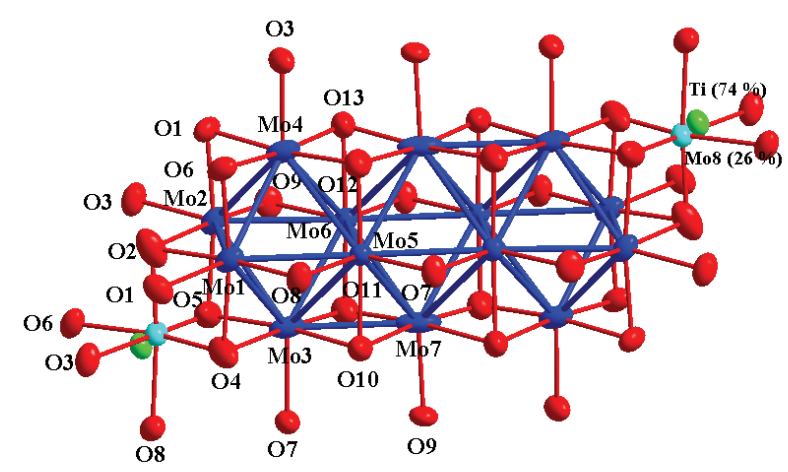

(a)

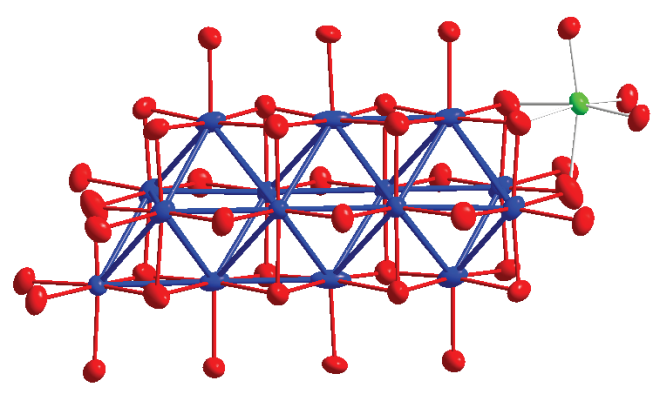

(b)

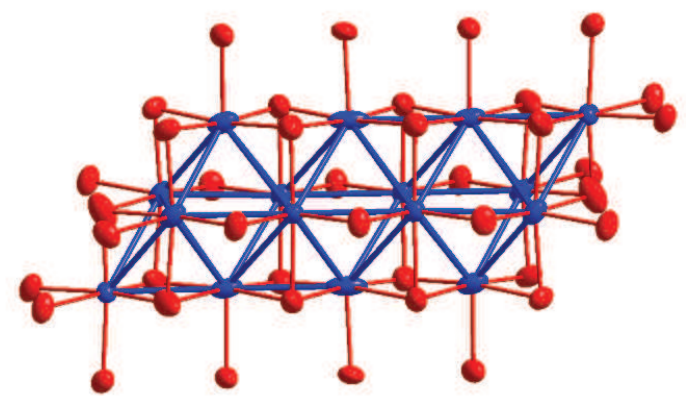

(c)

Figure 2. The (a) $\mathrm{Mo}_{14}$, (b) $\mathrm{Mo}_{15}$, and (c) $\mathrm{Mo}_{16}$ clusters with their oxygen and titanium environnements. 


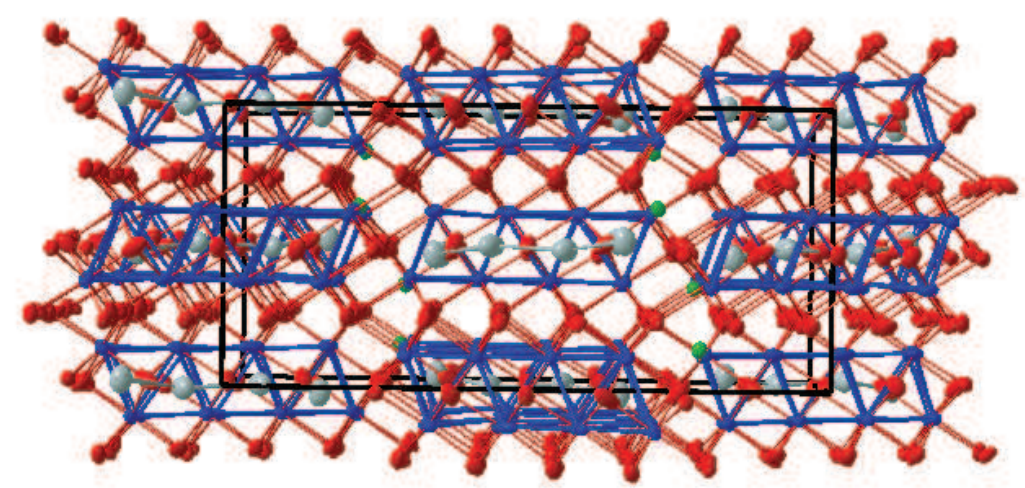

Figure 3. Perspective view of the crystal structure of $\operatorname{In}_{4} \mathrm{Ti}_{1.5} \mathrm{Mo}_{0.5} \mathrm{Mo}_{14} \mathrm{O}_{26}$ along the $b$ axis. 

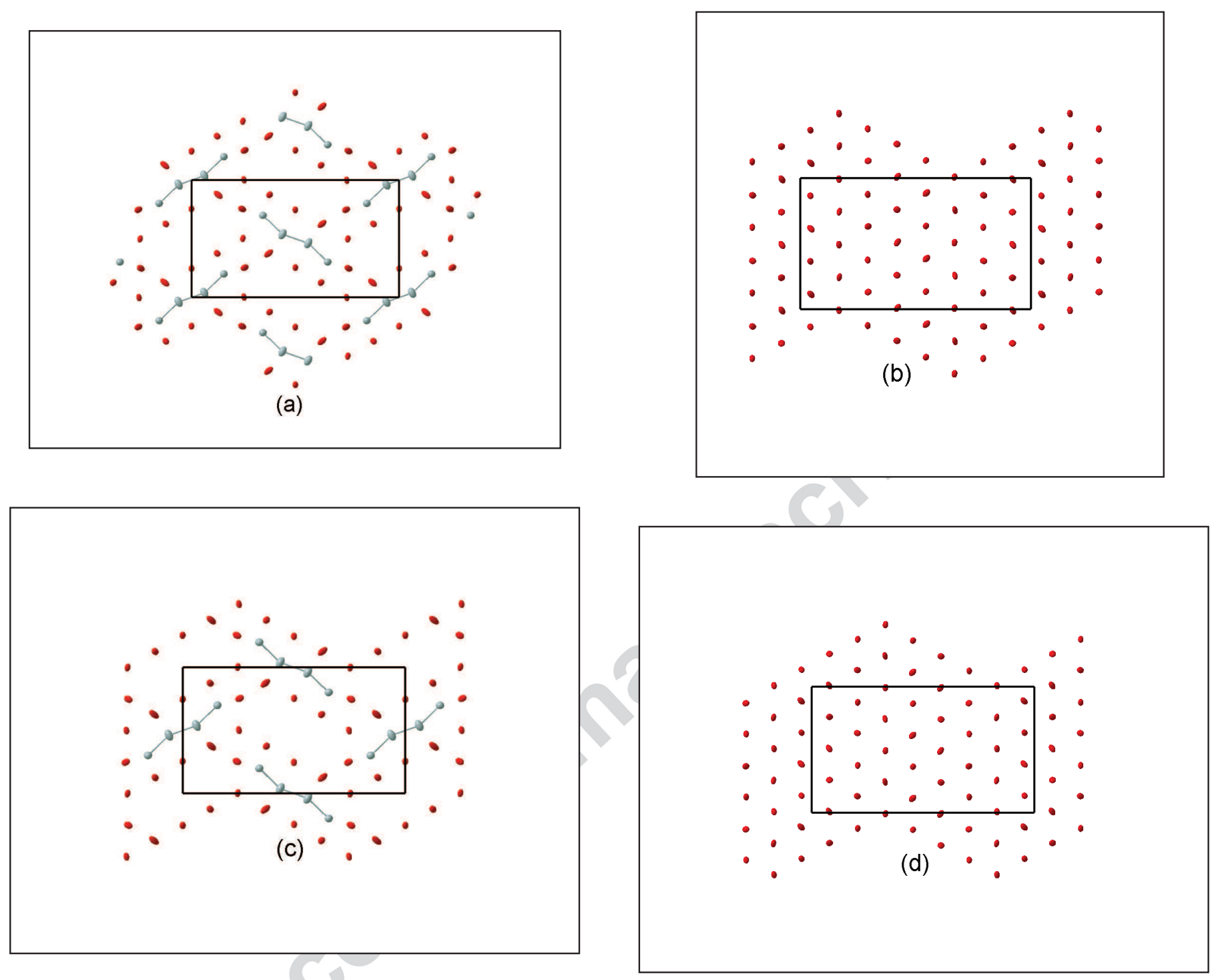

Figure 4. Arrangement of the oxygen and indium atoms within the $A B A C$ layers. 


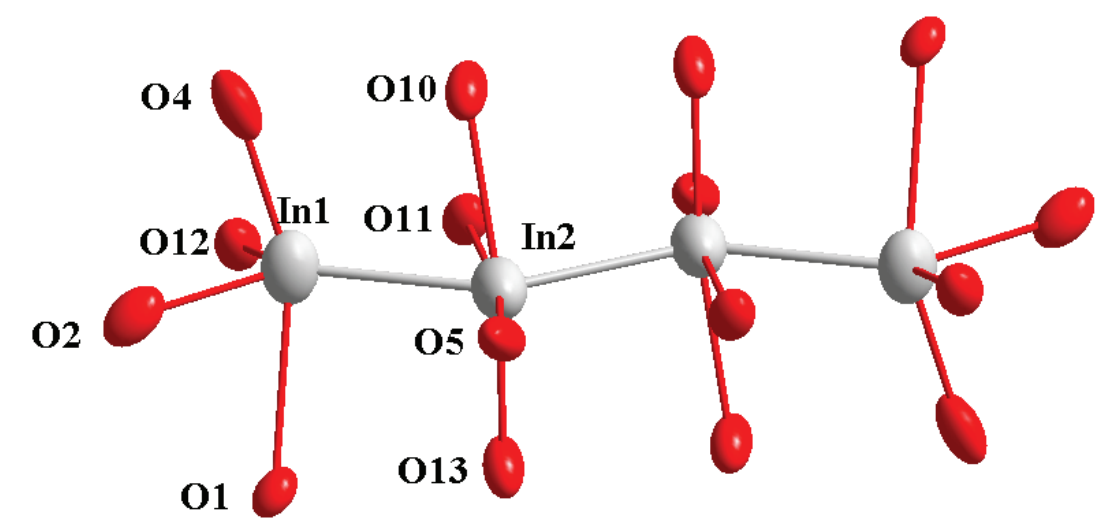

Figure 5. The tetrameric cation $\operatorname{In}_{4}{ }^{6+}$ with its oxygen environment. 


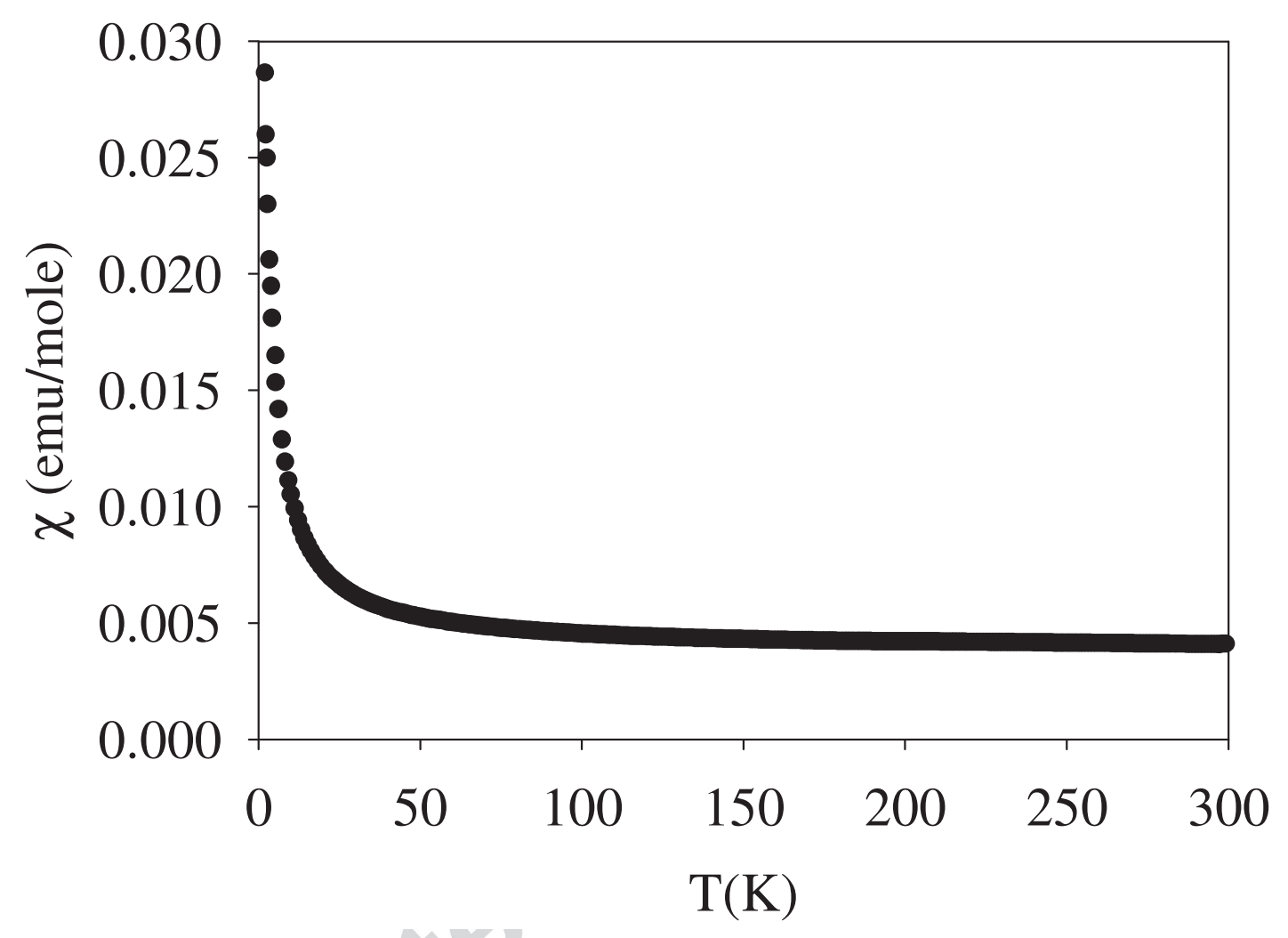

Figure 6. The temperature dependence of the molar magnetic susceptibility of $\mathrm{In}_{4} \mathrm{Ti}_{1.5} \mathrm{Mo}_{0.5} \mathrm{Mo}_{14} \mathrm{O}_{26}$. 


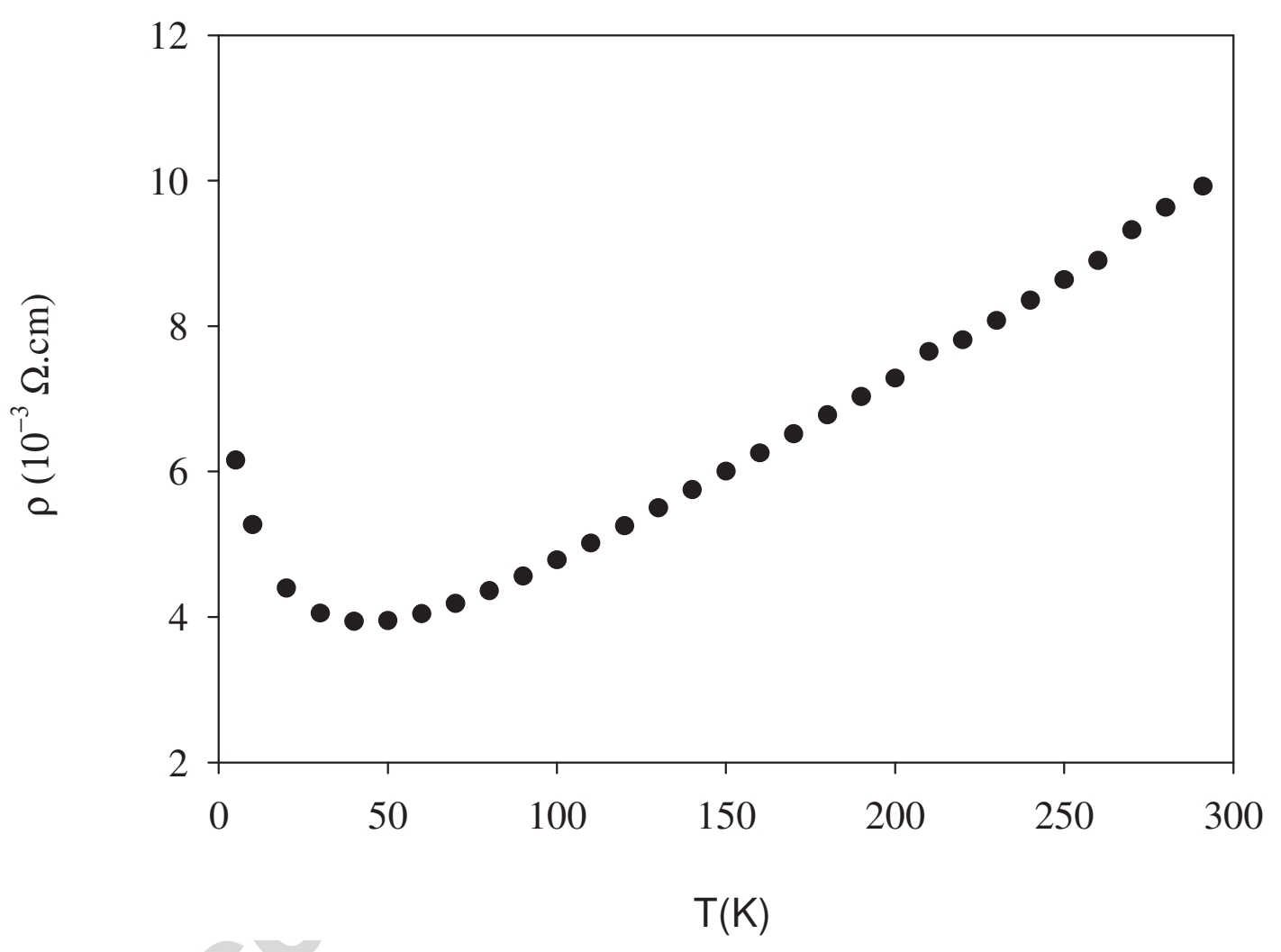

Figure 7. Temperature dependence of the electrical resistivity for $\operatorname{In}_{4} \mathrm{Ti}_{1.5} \mathrm{Mo}_{0.5} \mathrm{Mo}_{14} \mathrm{O}_{26}$. 


\section{Synopsis}

The novel reduced molybdenum oxide $\operatorname{In}_{4} \mathrm{Ti}_{1.5} \mathrm{Mo}_{0.5} \mathrm{Mo}_{14} \mathrm{O}_{26}$ has been synthesized by solid-state reaction at $1400^{\circ} \mathrm{C}$ for $96 \mathrm{~h}$ in sealed molybdenum crucibles. Its crystal structure contains in addition to $\mathrm{Mo}_{14}$ clusters the first examples of mono- and bi-capped trioctahedral $\mathrm{Mo}_{14}$ i.e. is the $\mathrm{Mo}_{15}$ and $\mathrm{Mo}_{16}$ clusters. Magnetic susceptibility measurements confirm the presence of $\mathrm{Ti}^{4+}$ cations and the absence of localized moments on the Mo network. Electrical resistivity measurements on a single crystal of $\operatorname{In}_{4} \mathrm{Ti}_{1.5} \mathrm{Mo}_{0.5} \mathrm{Mo}_{14} \mathrm{O}_{26}$ show a semimetallic behavior.

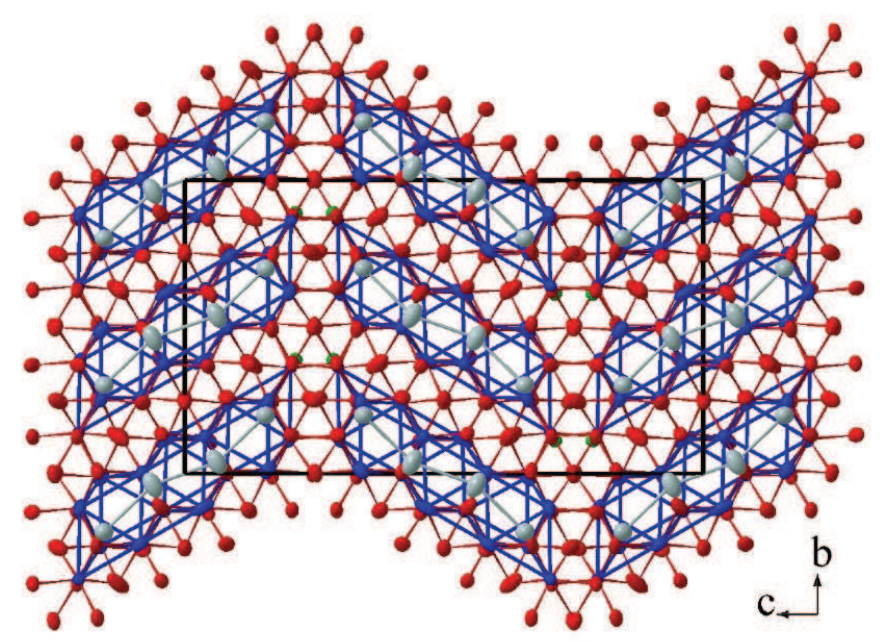


The cluster compound $\mathrm{In}_{4} \mathrm{Ti}_{1.5} \mathrm{Mo}_{0.5} \mathrm{Mo}_{14} \mathrm{O}_{26}$ containing $\mathrm{Mo}_{14}$ clusters and the new mono- and bi-capped trioctahedral $\mathrm{Mo}_{15}$ and $\mathrm{Mo}_{16}$ clusters: synthesis, crystal structure, and electrical and magnetic properties.

Philippe Gall, Thierry Guizouarn and Patrick Gougeon*

Laboratoire de Chimie du Solide et Inorganique Moléculaire, UMR CNRS 6226 - INSA,

Université de Rennes 1, Avenue du Général Leclerc, 35042 Rennes-Cedex, France.

We present here the synthesis, the crystal structure, and the electrical and magnetic properties of the new compound $\operatorname{In}_{4} \mathrm{Ti}_{1.5} \mathrm{Mo}_{0.5} \mathrm{Mo}_{14} \mathrm{O}_{26}$ in which $\mathrm{Mo}_{14}$ clusters coexist statistically with mono- and bi-capped trioctahedral $\mathrm{Mo}_{14}$ that is $\mathrm{Mo}_{15}$ and $\mathrm{Mo}_{16}$ clusters.

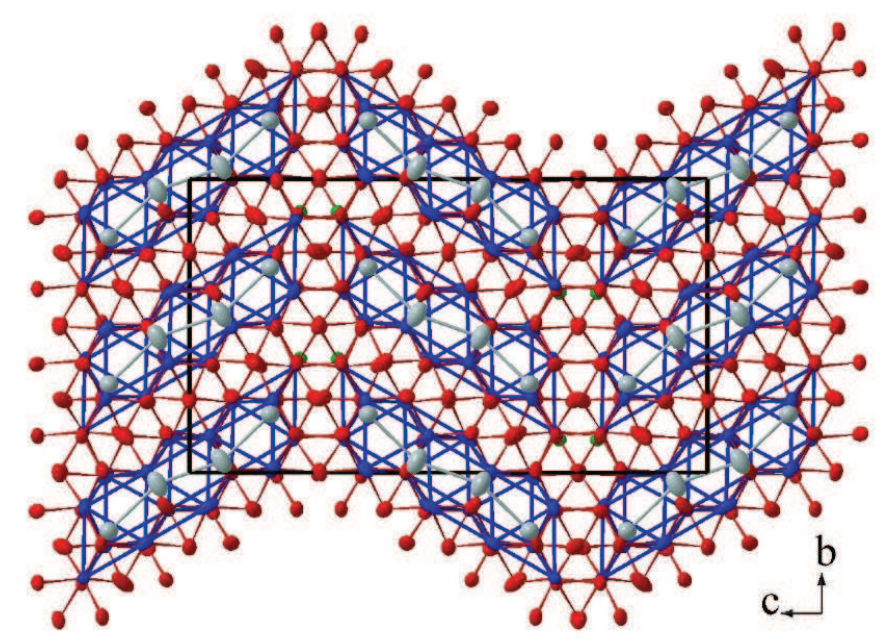


Highlights

. Single crystals of In4Ti1.5Mo0.5Mo14O26 were obtained by solid state reaction.

. The crystal structure contains Mo14, Mo15 and Mo16 clusters.

The indium atoms form $\operatorname{In} 4^{6+}$ bent chains.

Poorly metallic behavior.

. Absence of localized moments on the Mo network as well as on the Ti atoms. 
[9] K.V. Ramanujachary, M. Greenblatt, E.B. Jones and W.H. McCarroll, J. Solid State Chem. 37 (1981) 393.

[10] C.C. Torardi, R.E. McCarley, J. Solid State Chem. 102 (1993) 69.

[11] R.E. McCarley, K.-H. Lii, P.A. Edwards and L.F. Brough, J. Solid State Chem., 57 (1985) 17.

[12] D. Jung, B.-H. Lee, S.-J. Kim and W. Kang, Chemistry of Materials 13 (2001) 1625. 